Portland State University

PDXScholar

5-8-1975

\title{
A Study of Local Union Business Agents in Portland, Oregon Area
}

Lillian L. Morrison

Portland State University

Follow this and additional works at: https://pdxscholar.library.pdx.edu/open_access_etds

Part of the Labor Economics Commons

Let us know how access to this document benefits you.

\section{Recommended Citation}

Morrison, Lillian L., "A Study of Local Union Business Agents in Portland, Oregon Area" (1975).

Dissertations and Theses. Paper 2420.

https://doi.org/10.15760/etd.2419

This Thesis is brought to you for free and open access. It has been accepted for inclusion in Dissertations and Theses by an authorized administrator of PDXScholar. For more information, please contact pdxscholar@pdx.edu. 
AN ABSTRACT OF THE THESIS OF Lillian L. Morrison for the Master of Science in Economics presented May 8, 1975.

Title: A Study of Local Union Business Agents in the Portland, Oregon Area.

APPROVED BY MEMBERS OF THE THESIS COMMITTEE:

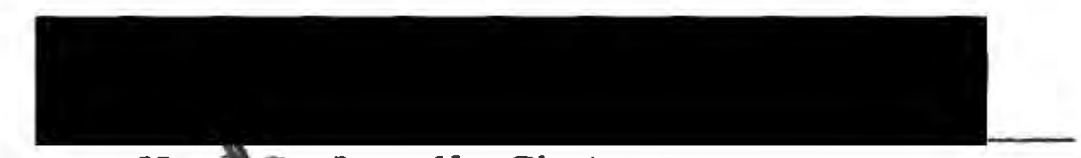

Hugh G. Lovell, Chairman

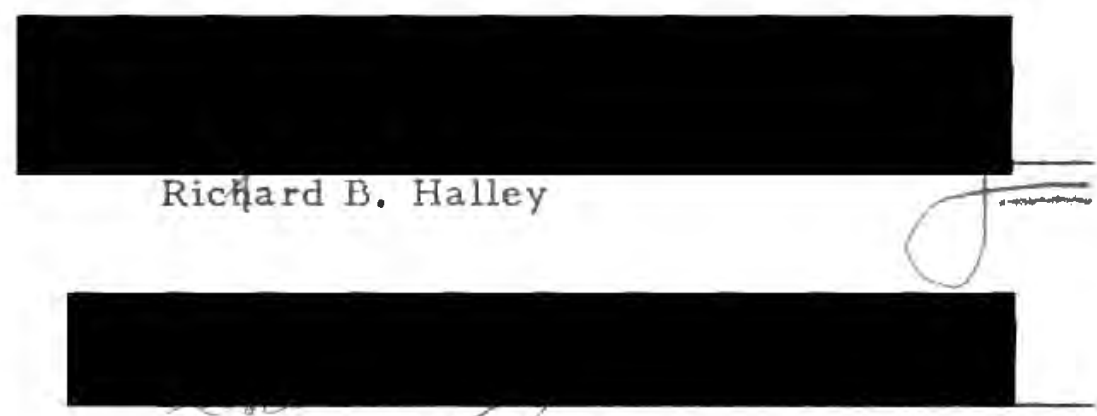

Helen Y. Waetrer

Labor unions are an integral part of the economy of the United

States. At the grass roots, union influence and/or effectiveness depends on the local union organization, its management, and its relationship to and involvement in community affairs. This influence and involvement is focused on the local union leadership in the person of the business agent. A substantial body of literature exists on leadership in general as well as specific information about leadership in labor unions, and includes contributions from the fields of Sociology and Psychology as well as Economics. This research 
paper is a study of local union business agents in the Portland, Oregon area comparing the $m$ to and categorizing them in accordance with the criteria set up by others as well as suggesting new divisions that were found useful in the course of this research.

Data for this research were obtained from personal interviews with the agents of thirty union locals ranging in size from the largest local in the area to one of the smallest, and by studying the yearly financial reports on file in the local office of the Labor-Management Services Administration of the United States Department of Labor. This research tabulates the thirty business agents as to age, sex, family background, education, length of union membership, and reasons for seeking office. Gross salaries paid to the local business agents are also tabulated along with a discussion of how the se salaries are set. Total membership figures are given so that a per capita expense figure can be estimated for an individual member's contribution to the support of his business agent.

From the results of this survey one may conclude that. effective leadership was in evidence in at least some of the locals studied, leadership that provided not only economic services but inspiration toward intellectual growth and toward increasing effective union action in helping solve some of the complex social and economic problems of the area. One may also conclude that local union organizations in the area are managed by competent, honest, industrious 
men and women who recognize that what benefits the working men and women of the area, benefits the entire community. 
A STUDY OF LOCAL UNION BUSINESS AGENTS

IN THE PORTLAND, OREGON AREA

(1969)

by

LILLIAN MORRISON

A thesis submitted in partial fulfillment of the requirements for the degree of

\author{
MASTER OF SCIENCE \\ in \\ ECONOMICS
}

Portiand State University

1975 
TABLE OF CONTENTS

PAGE

LIST OF TABLES

ii

CHAPTER

I RATIONALE AND METHODOLOGY OF STUDY.. I Rationale Methodology of Study

II EMERGENCE OF THE BUSINESS AGENT ....

III THE BUSINESS AGENT IN PORTLAND, OREGON $\ldots \ldots \ldots \ldots \ldots \ldots \ldots \ldots \ldots \ldots 19$

IV MONETARY AND NON-MONETARY RETURNS

TO PORTLAND BUSINESS AGENTS ....

V SUMMARY AND CONCLUSIONS ............ 50

APPENDIX

A LOCAL UNIONS STUDIED, PORTLAND, OREGON $\ldots \ldots \ldots \ldots \ldots \ldots \ldots \ldots \ldots$

B RUTGERS' SOCIAL ATTRIBUTE INVENTORY .. 55

C INTERVIEW QUESTIONNAIRE ............. 57 


\section{LIST OF TABLES}

TABLE

PAGE

I Age Distribution of Portland Business Agents,

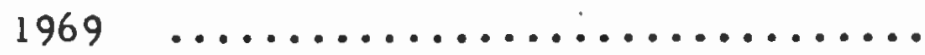

II Education of Portland Business Agents, 1969

III Length of Union Membership, Portland Business Agents, $1969 \quad \ldots \ldots \ldots \ldots \ldots \ldots \ldots \ldots$

IV Business Agents' Salaries, Membership,

Per Capita Costs, 1969 ............. 


\section{CHAPTER I}

\section{RATIONALE AND METHODOLOGY OF STUDY}

\section{Rationale}

Labor unions directly affect about a quarter of the United States labor force and indirectly affect the entire work force and the whole economy: 1 Large unions and their national presidents receive much attention from national politicians and the national press, but many local nonfactory unions and their business agents are of similar importance to the public and the business communities of the urban areas where most workers live. Nonmanufacturing industries provided $70.2 \%$ of all nonfarm jobs in 1963, up from $65.7 \%$ in $1951,^{2}$ and because this trend is expected to continue as service industries increase, it might be worthwhile to take a closer look at the officials who administer some of the local unions connected with the se industries.

This paper is based on the proposition that a powerful inter-

${ }^{1}$ Weiss, Leonard W., Economics and Society New York: John Wiley \& Sons, Inc., 1975, p. 217.

${ }^{2}$ Kennedy, Van Dusen and Wilma Rule Krauss. The Business Agent and His.Union, Berkeley: Institute of Industrial Relations, University of California, 1964, p. viii. 
national union derives its power and draws its strength from the numerous local union organizations across the country that finance the international, explain the union view to the local press and public, and promote and foster union loyalty among the working men and women of this country. In turn the local unions are influenced by the men who administer their day to day affairs, the business agents. One of the few studies of local union business agents in the United States was made by Van Dusen Kennedy and Wilma Rule Krauss in a pamphlet entitled, "The Business Agent and His Union," published in 1955. (A revised edition was published in 1964.) Research for this work was done in the San Francisco area in 1951, and the authors have observed a continuing demand for their pamphlet from labor organizations, management, government officials, schools and universities, and the general public. The sustained interest in this work indicated that a similar study of business agents in the Portland, Oregon area may be a valuable addition to the field of labor knowledge.

This paper proposes to assess the personal characteristics, motivation in seeking office, and the leadership qualities of the men who control some of the local unions in this area, as well as, to investigate the monetary and non-monetary rewards resulting from holding union office. 
Methodology of Study

Business agents have played an important role in the American Labor movement. Chapter II provides a brief history of the emergence of the business agents and details some of their functions and accomplishments. Following this, Chapter III describes some of the business agents in the Portland area in a context of the administration of union activities. Remuneration of the business agent is the subject of Chapter IV. Finally, summary and conclusions are given in Chapter $\mathrm{V}$.

In the balance of this chapter several elements dealing with identification and classification of business agents are discussed in depth along with techniques of developing information from Portland area locals.

Business agents have been characterized in various ways by writers interested in unionism. Some of these broad methods of classification are:

I. Chinoy classified local union officers as (1) "accidental leaders," pushed into office by a sudden unforeseen turn of events; (2) the "ambitious leader," who clearly sees the advantages to be had by acquiring a position in the union and views such a position as a means for satisfying ambitions that had been frustrated or were out of reach; (3) the "ideological leader," a man who is deeply committed to the principles of unionism and who views the job as an opportunity 
for helping his fellow workers -- for doing some "good" for the local.

II. Gouldner classified union officers as (1) "business unionists," those leaders who view the office as an entrepreneur views a business venture.-- an opportunity for money, prestige, security, personal satisfaction; (2) "progressive unionists" -- those who see the trade union office as a calling -- an institution through which he can work for "humanity. "6

III. Sayles and Strauss classified union leaders as (I) "administrators," men who are problem-oriented in their approach to their positions, efficient, good executives and public-relations men, quick-thinkers in debate, but lacking warmth in relationship with members: (2) "social leaders" who seem more interested in personalities and interpersonal relations than in problems and issues confronting the local, inefficient perhaps but generally trusted and well liked, even defended for their shortcomings by the membership. 7

IV. Barbash classified local union officers as (1) "charismatic leaders," public-relations minded men who think in broad scope and

${ }^{5}$ Chinoy, Eli. "Local Union Leadership," in Alvin W. Gouldner (ed.), Studies in Leadership, New York:Harper and Bros., 1950, p. 165.

${ }^{6}$ Gouldner, Alvin W. "Attitudes of 'Progressive' Trade Union Leaders," American Journal of Sociology, LII (1947), pp. 389-92.

${ }^{7}$ Sayles, Leonard $R$. and George Strauss. The Local Union: Its Place in the Industrial Plant, New York, Harper \& Brothers, 1953, pp. 124-25. 
magnitude, who develop new, efficient, creative solutions to problems confronting the community as well as the local union; (2) "ideological leaders," committed not to the traditional Marxist ideology but to "some reflective view of society, of labor-management relations of the role of the union"; (3) "high-powered leaders," not as inventive as the charismatic leader or as philosophical as the ideological leader - a leader more likely to extend his area of action beyond the local into the community activities; (4) the "errand boy," a leader so overwhelmed by the complexities of the job and by his need to deal with all demands put upon him that he has lost the capacity to lead and frequently must call on the international representative for help. 8

While all these four detailed classifications have merit, two of the above categories can be eliminated as far as fundamental concepts of leadership are concerned - - the "accidental" leader and the "errand boy." "Accidental" refers to the method of obtaining office rather than to the conduct of the office; and, while "errand boy" may be an officer, he is not a leader in the sense that a leader advances the goals of the local as seen by a majority of its members. In Professor Barbash's words, "errand boy had lost the capacity to lead. "9

${ }^{8}$ Barbash, Jack. Labor's Grass Roots, New York, Harper \& Brothers, 1961 , pp. 79-92.

${ }^{9}$ Barbash, op. cit. , p. 90. 
This leaves Chinoy's "ideological" leader, similar to the "progressive" leader described by Professor Gouldner, and Chinoy's "ambitious" leader, similar to Gouldner's "business" unionist. The terms, "administrators" and "social leaders" used by Sayles and Strauss and "charismatic" and "high-powered" used by Barbash refer more to personality traits than to fundamental concepts of local union office responsibility. "Administrators" may approach their jobs in an objectively analytical way; and, "social leaders" in a subjectively emotional way, but this does not tell us whether their fundamental views of trade union office holding is one of commitment to the ideal of bettering the lot of the working men, or commitment to personal advancement -- the "ideological" leader or the "ambitious" leader. (These two views, of course, are not mutually exclusive and perhaps a leader should be categorized as primarily "ideological" or primarily "ambitious.")

A division of trade union leaders into the se two categories, primarily "ideological," and primarily "ambitious," seems appropriate based on the above mentioned lite rature; but, another basic division is apparent and will be used in addition to those described to categorize the officers in this study: (1) An officer may be first and foremost a blue-collar worker who has been entrusted by his fellow workers with an office in the local trade union. When his term of office is over he will rejoin his brother unionists on the job. (2) An 
officer may feel he has risen above blue-collar status, and if defeated for union office in the future will find other managerial-type employment in industry, government, or perhaps in the international office. The first type will be referred to as a "worker-officer" and the second as a "managerial-officer."

For the purpose of this study the definition of leadership used in the choice of which union official to interview was: A leader is "a person who exerts special influence over a number of people." $10 \mathrm{Al}$ most everyone has some special influence over at least a few others, but leadership, which is personality in action under group conditions, requires that this special influence be exerted over a relatively large number of people. ${ }^{11}$ The office holder was considered the actual leader as well as the titular leader because, while leadership might be held by any person around whom group members focus their behavior, such a person, if he represented the majority of the group, would most likely be in office. Therefore, although leadership and office holding may not be synonymous, for the purposes of this study, it is assumed that the elected, highest-paid official is the leader of the local. and has the most authority in the day-to-day affairs of the local union. The smaller unions have just one paid official, while

${ }^{10}$ Bogardus, Emory S. Leaders and Leadership, New York: D. Appleton-Century Co., Inc., 1934, p. 3

${ }^{11}$ Ibid., p. 4. 
the largest in this study has eighteen paid, full-time officers.

In two-thirds of the locals observed the official with the highest salary was called secretary-treasurer, or business manager and financial secretary. The remaining one-third was most often called simply business agent, a term which will be used throughout this paper because of its convenience and because it is generally understood to refer to an elected, full-time, paid official of a local union. 12

The two major sources of information about union business agents used in this study were personal interview questionnaires and local union records. For assessing the personal characteristics of local business agents, personal interviews were made using the "Rutgers'Social Attribute Inventory,"13 a subjective rating which helped to specify the particularimage of business agents. In addition, a series of forty-one questions was designed to elicit four categories of information from each respondent: (1) Basic data information, (2) job performance information, (3) information on policy objectives, and (4) information concerning internal

12 of the thirty business agents approached for this study only one refused an interview, the secretary-treasurer of a teamster's local. The president of this local, with the required approval of the secretary-treasurer, was interviewed instead. This instance may suggest that, at least in the Portland area locals, salary and authority ascend together.

13 Obtained from Psychology Department, Portland State University. (William D. Wells, Psychometric Affiliates) 
workings of the local. 14

The first three interviews were conducted without the questionnaire (they were redone later using the questionnaire) but the material gained was too diverse to sort out in any systematic way. The questionnaire was used so that the same specific information would be available on each subject along with the additional voluntee red information.

To determine the salaries of the business agents and the size of the locals they represent, the reports filed by each union local, required under Public Law 86-257, Labor-Management Reporting and Disclosure Act of 1959, were examined before the interviews were made.

To select the union locals to be used in the study from the ninety-seven locals listed in the 1969 Labor Organizations Telephone Directory of the Portland, Oregon area, thirty locals were chosen systematically in an effort to obtain a range of union-membership size. The alphabetical listing of the Directory was the universe of unions. (See Appendix A)

The sample included the largest local in the area, Local \#701, Hoisting and Portable Engineers, with a membership of 5,800;

${ }^{14}$ Adapted from Miller, Robert W. , Frederick A. Zeller, Glenn W. Miller. The Practice of Local Union Leadership, Columbus: Ohio State University Press, 1965, pp. 214-267. 
and the smallest, Local \#70, International Ladies' Garment

Workers, membership 40. This sample was large enough to include various styles of leadership, but small enough to be surveyed by one interviewer. 


\section{CHAPTER II}

\section{EMERGENCE OF THE BUSINESS AGENT}

The need for what today is called the business agent can be traced to the eventful day, May 4, 1886. On that day a bomb exploded in the Chicago Haymarket Square, which may not have been heard around the world but was heard across the length and breadth of the United States.

Public sentiment immediately turned against organized labor, as represented by the one million Knights of Labor which up until that time enjoyed greater general acceptance than had any previous labor organization in the history of the United States. Lack of public support led to the decline of this group creating a void in union organization by the early 1890 s. This void was filled by the newly formed American Federation of Labor, a group that approached the organization of the laboring man somewhat differently than had the Knights of Labor. Vague ideals of working class solidarity were now replaced by business unionism. If "the business of America is business, "1 the business of the labor union is to take a page from the

1Stone, Irving. "Calvin Coolidge: A Study in Inertia." The Aspirin Age, Ed. Isabel Leighton. New York: Simon \& Schuster, Inc., 1949, p. 147. 
book of business, organize along craft lines, and let each craft win for its members a larger share of the product.

The chaos in the labor movement created by the Haymarket bomb gave not only labor an opportunity for a new tack, it also gave the employers' as sociations throughout the country an opportunity "to put the laborer in his place, for the bomb had inflamed the righteous public against the efforts of the underdog to lift himself to a higher level. "2 In such an environment business men blacklisted known labor leaders and organizers. The mere possession of a ticket (a union card) by a workman meant instant dismissal from the job. An unemployed union man riding the rails in search of work could anticipate a beating by company "guards" if detected. 3

It soon became apparent that if unions were to survive they would need a representative who was not dependent for his livelihood on the whim of the employer, a fearless representative who could not be intimidated by the employers' armed "guards." The position of walking delegate, or business agent as he is called today, emerged to fill this need. A few walking delegates had already existed, but with increased activity in the labor movement, they developed as an essential element.

In 1917, R. F. Hoxie delineated two opposing views of the

${ }^{2}$ Adamic, Louis. Dynamite: The Story of Class Violence in America, Revised Edition, Gloucester, Mass., Peter Smith, 1963, p. 97.

${ }^{3}$ International Brotherhood of Electrical Workers. History and Structure of the IBEW, Washington, D. C., 1967, p. 4. 
business agent. Businessmen saw him as "an autocrat who goes about browbeating employers and ordering out cringing workmen at his own sweet will and for his own profit. $"{ }^{4}$ Unionists described the business agent as "merely a useful and harmless local executive officer. $"{ }^{5}$ Theoretically this latter view may have been correct but actually the useful servant could and sometimes did become the irresponsible autocrat that businessmen observed. 6

Describing the duties of these business agents of the first two decades of the 20th century Hoxie stated:

The peculiar duties of the walking delegate are such as to give him easy ascendency over the rank and file. He looks out for employment for them; his duties lead him over the whole local field of labor, he knows where jobs are and how to get them, he can keep a man at employment, or he can keep him from it; he looks after the finarices of the union, he sees that the members pay their dues, or he can make it easy for them; he presents grievances to the employer and can argue the case, for he is not dependent on the "boss" and does not fear him; he can help one to agreeable conditions of work or he can leave him unassisted and unprotected. Clearly he is a man to keep on the right side of, and to keep "in" with. To be sure his term of power is brief and the union can turn him out if it wants to, constitutionally. Practically it cannot and will not once he begins to con-

${ }^{4}$ Hoxie, Robert Franklin. Trade Unionism in the United States, New York, D. Appleton and Company, 1917, p. 182.

${ }^{5}$ Ibid. , p. 182.

${ }^{6}$ Seidman, Harold. Labor Czars, New York: Liveright Publishing Corporation, 1938, pp. 11-26. 
solidate his power. When the union thinks of choosing his successor, there is no one in the union who can do his work half so well as he. He is acquainted with the whole field of operations, and has an accumulation of knowledge that the ordinary worker, held to his bench or to his machine for nine or ten hours a day, cannot have acquired. These ordinary workers naturally come more and more to rely on his judgment. Moreover, he has learned how to deal with men in general and how to deal with employers in particular; he has learned how to talk and to persuade.

- . The essential thing is that the walking delegate does not have to take his orders from or report to the national officers. He is responsible not to his superior officer but to his inferiors - the rank and file who elect him. 7

Whatever the paid full-time official of the local union may be called - walking delegate, financial secretary, business manager, business agent, executive secretary, or any combination of these terms, his duties are the same as Hoxie indicated fifty years ago. The business agent still represents the workers of his local on all questions which arise concerning the job and the union contract: questions about pay, working conditions, vacations, overtime, holidays, work rules, safety, promotions, lay-offs. One of his most important duties is to represent the union members in new contract negotiations. However, the modern business agent's duties go beyond the bread and butter issues. He is consulted on family problems, as

$$
7 \text { Hoxie, op. cit., pp. 183-184. }
$$


well as legal and social problems. Today's business agent views himself as a fellow unionist and personal friend.

Labor history and literature provide many instances of influential, colorful business agents - for example, Jacob F. Friedrick, business agent of Lodge 66 of the International Association of Machinists in Milwaukee, Wisconsin from 1919 to 1929. Mr. Friedrick worked with Professor John R. Commons to prepare the first unemployment compensation bill introduced into the 1921 Wisconsin legislature. It finally became law in 1932 - the first of its kind in the nation. ${ }^{8}$ Friedrick helped establish the Milwaukee Labor college in 1920, a night school for workers sponsored by the Federated Trades Council. ${ }^{9}$ After several years as regional director of the American Federation of Labor, Mr. Friedrick accepted the position of general secretary of the Milwaukee Federated Trades Council. He is a labor man generally respected throughout the state where one official said of him, "He does not fail to push his people's point of view, but he does it as a reasonable man. "10 A management man stated, "We don't square with his views completely, of course. But

${ }^{8}$ Pomfret, John D. ''Jake' Friedrick of the Milwaukee Federated Trades Council," in Unions and Union Leadership, Jack Barbash, editor, New York: Harper \& Brothers, 1959, p. 65.

$$
\begin{aligned}
& { }^{9} \text { Ibid., p. } 66 . \\
& { }^{10} \text { Ibid. , p. } 64
\end{aligned}
$$


he is a perfectly fine gentleman. Once his word is given you can trust him. "11

Another respected, effective business agent is Andrew $J$. Mulrain of Local 1159 of the International Brotherhood of Electrical Workers in Newark, New Jersey. Mulrain joined the IBEW in 1937 and was elected business agent of Local 1159 in 1950. The employers with whom Mulrain deals praise his honesty and fairness, say that they can depend on what he says. Mulrain is on the board of directors of the Eastern Union County (N.J.) Community Chest and was appointed to the nonpaying but influential post of fire commissioner in 1953. 12

Harry Van Arsdale, the business agent of Local 3 of the IBEW in New York City illustrates just how important a local leader can be. Mr. Van Arsdale held his local post thirty-five years before moving up to treasurer of the international union. ${ }^{13}$ In 1961 he won for his membership a standard twenty-five hour workweek, a goal that no other local has yet attained. As leader of the 1,200,000 member New York City Central Labor Council Van Arsdale is a powerhouse in New York politics, while his creative and imaginative leadership

$11_{\text {Ibid. . p. } 64 .}$

12 Barbash, Jack. Unions and Union Leadership, New York: Harper \& Brothers, 1959, pp. 99-102.

13 "The Royal Families," Fortune, December 1968, p. 107. 
of Local 3 sets an example for other business agents to emulate. Of course, few local unions can boast the 38,000 membership of Local 3. 14 In discussing this local union one astute writer on labor affairs states, "The most important single force within the administrative life of the union is the personality, human sympathy, historical perception, philosophy and energy" of the business manager. 15

Not all publicized local labor leaders have had a beneficent effect on unionism. From 1901 to 1903, when he was expelled from the union, Sam Parks, business agent of the New York City Structural Iron Workers' Local, drove the wages of iron workers up from $\$ 2.50$ per day to $\$ 4.50$ a day all the while enriching himself far beyond his $\$ 48.00$ per week salary. ${ }^{16}$ During this same period, Martin B. "Skinny" Madden, business agent of the Chicago Steamfitters Helpers' local, dominated the building trades of that city promoting his own interests rather than the interests of the union workmen. His philosophy of life and labor was expressed in the phrase, "Show me an honest man and I'll show you a fool. "17 Whether James R. Hoffa,

${ }^{14}$ Ibid. , p. 107.

${ }^{15}$ Neufeld, Maurice. Day In and Out with Local 3, IBEW, Ithaca: Cornell University Press, 1951, p. 4.

$$
\begin{aligned}
& { }^{16} \text { Seidman, op. cit., p. } 13 . \\
& 17 \text { Ibid., p. } 33 .
\end{aligned}
$$


one time business agent of Local 299 of the International Brotherhood of Teamsters of Detroit, Michigan, should be included in this group is probably still open to debate; but, such local leaders do little or nothing to advance labor's cause with the public. However, they do explain some of the antagonism that organized labor frequently encounters. 


\section{CHAPTER III}

\section{THE BUSINESS AGENT IN PORTLAND, OREGON}

In this chapter I propose to look at the business agents in the Portland area, their personal characteristics, educational and family backgrounds, reasons for seeking union office, how they obtained the office, and how they view their duties and their responsibilities toward their members. Additionally, I will assign many local business agents to the categories of leaders described in Chapter I.

Obviously, none of the agents is as famous or infamous as those mentioned in Chapter II, but Portland is not as large or indus tialized as Newark, New York, Chicago, or Detroit, so a labor leader in this area could not influence the large numbers of workers or affect industry to the extent that business agents in larger cities can.

Not all local unions have full-time, paid business agents. One assistant business agent stated, "You need a group of at least a hundred working members to form a workable local union with a paid business agent." In this study only four of the thirty locals sampled were directed by unpaid, part-time officers. The smallest local (forty members) was run by a retired worker, who has been vitally interested in unions since the 1920s. The other three unpaid officers, a secretary-treasurer, a business agent, and a president, 
represent locals of eighty-two, two hundred, and fourteen hundred members, respectively. These three men work full-time on the job and handle union affairs during their time off. Two are on the night shift and have time free during the day for union business, the other one must take care of union affairs on his lunch hour.

Twenty-five years ago, a knowledgeable writer on labor affairs stated:

Whether or not a local has a business agent depends upon its size. If its membership is 2,000 or more, to strike an approximate figure, it will probably be able to afford a business agent. ${ }^{1}$

Only five locals in this survey have a membership of two thousand or over, yet twenty-six of these locals have full-time, paid business agents. Fifteen of these twenty-six locals have more than one full-time, paid administrative official - one local having eighteen such officers. Whether a local functions more effectively with a fulltime, paid business agent depends more on the type of work the members are engaged in than on the number of members involved. The building trades, where work sites change frequently, need business agents for job assignments as a convenience to the employers as well as the workmen. On the other hand, one of the locals in this stidy has fourteen hundred members and no paid official, but this local deals with only one employer, so even though the local is slightly larger than the median, 1200, in this study, it does not require the services of a paid business agent.

${ }^{1}$ Barbash, Jack. Labor Unions in Action, New York: Harper \& Brothers, 1948, p. 113. 
There are various ways a working member of a union local can become a paid full-time official. Usually a period of volunteer service in his local precedes election to a paid office. This was true in every instance in this survey with one exception. The methods of obtaining office ranged from "taking my turn" to a bitter battle with an incumbent which involved the intervention of the enforcement officer of the local office of the Labor-Management Services Administration of the United States Department of Labor.

The most popular reason for seeking a position as business agent was a view of the job as an opportunity to accomplish something worthwhile for the local, usually a specific goal such as bettering working conditions or raising an inadequate wage schedule; another reason, a rather close second, was dissatisfaction with an incumbent. Four officers said that they had been requested by either the membership, the International Office, or both, to seek the job. In one instance the president of a 1400-member local was requested to run for office and was the only member to do so. Several recalled hazardous working conditions; inadequate pay, e.g., seventy hours for $\$ 18.00$, and no compensation for injury on the job. One business agent recalled that when his union was formed women workers paid the employer $\$ 5.00$ per week to learn the trade. He felt that this payment continued weeks after their output made a significant contribution to the employer's profit picture.

As other writers have noted, the majority of business agents are men. In this study there are twenty-seven men and three women. As might be expected the women represent locals with a preponder- 
ence of women workers, specifically the International Union of Laundry, Dry Cleaning and Dye House Workers, Hotel and Restaurant Employees, and the Poultry Workers of the Amalgamated Meat Cutters.

As a group the Portland business agents presented a most favorable impression in their manners, personal appearance, communication skills, and general demeanor, being in no way inferior to their counterparts in the business community, in education, or in government. If anything these union leaders were more friendly, less harried and abrupt than businessmen often appear to be, even though some of them had very full schedules and an interview had to be arranged well in advance. With one exception, no one was reluctant to talk to the interviewer, and the majority of business agents seemed to welcome the opportunity to present a factual picture of a local union officer to whatever audience might be involved.

These business agents were a mature group, ninety per cent of them being over forty years old. (See Table I.) Twenty-five were married, three widowed, one single, and one divorced. They maintain homes, raise families, pursue the same hobbies as other working Americans, although most indicated that they have less time for recreation than they would like and perhaps less than have the workmen they represent.

The median age of business agents in this survey was in the 50-59 year grouping, (specific ages were not asked), which is higher than the median age of 43.3 years for the general population in Oregon of Specified Managers and Administrators, a comparable 


\section{TABLE I}

AGE DISTRIBUTION OF PORTLAND BUSINESS AGENTS, 1969

\begin{tabular}{l|c|c|c|c|c}
\hline Ages & $20-29$ & $30-39$ & $40-49$ & $50-59$ & Over 60yr \\
\hline Men & 1 & 2 & 9 & 10 & 5 \\
\hline Women & & & 2 & & 1 \\
\hline Totals & 1 & 2 & 11 & 10 & 6 \\
\hline
\end{tabular}

category. ${ }^{2}$

Twenty-five of the agents interviewed had two or less dependents, and only five had three to five dependents. None had more than five. One explanation for this, of course, is their ages.

Considering their ages, it is surprising to find three out of this group have college degrees and seven have had some formal college work. One business agent interviewed holds a regular five year teaching certificate in the state of Oregon. Twenty-six are high school graduates. (See Table II.)

Ten percent of the business agents in the survey presented in Table II have college degrees, while twenty-nine percent of Specified Managers and Administrators in the U. S. census for Oregon have

${ }^{2} 1970$ U.S. Census data. Table 174 , Characteristics of Population, Oregon, part 39, p. 442. 
TABLE II

EDUCATION OF PORTLAND BUSINESS AGENTS, 1969

\begin{tabular}{c|c|c|c|c|c}
\hline \hline $\begin{array}{l}\text { 8th } \\
\text { Grade }\end{array}$ & $\begin{array}{l}\text { Jr. } \\
\text { High }\end{array}$ & $\begin{array}{l}\text { High } \\
\text { School }\end{array}$ & $\begin{array}{l}\text { H. S. } \\
\text { Grad. }\end{array}$ & $\begin{array}{l}\text { College } \\
\text { Work }\end{array}$ & $\begin{array}{c}\text { College } \\
\text { Degree }\end{array}$ \\
\hline 1 & 1 & $\begin{array}{l}1(3 \text { yrs. }) \\
1(2 \text { yrs. })\end{array}$ & 16 & 7 & 3 \\
\hline
\end{tabular}

college degrees. ${ }^{3}$

With one exception, a wife was asked to serve out her husband's term in office upon his sudden death, all the business agents surveyed had a period of union membership ranging from a five-year minimum to a forty-two-year maximum, the average union membership of the group was approximately 27 years. (See Table III)

\section{TABLE III}

$$
\begin{gathered}
\text { LENGTH OF UNION MEMBERSHIP, } \\
\text { PORTLAND BUSINESS AGENTS, } \\
1969
\end{gathered}
$$

\begin{tabular}{c|c|c|c|c|c|c|c|c}
\hline \hline yrs. & $5-9$ & $10-14$ & $15-19$ & $20-24$ & $25-29$ & $30-34$ & $35-39$ & $40-45$ \\
\hline 1 & 2 & 1 & 4 & 3 & 7 & 5 & 5 & 2 \\
\hline
\end{tabular}

In each instance, except the one noted above, these leaders had come

${ }^{3} 1970$ U.S. Census data. Table 179, Characteristics of Population, Oregon, part 39, p. 469. 
from the ranks and had been in office from less than a year to over thirty-five years, the average being nine and one-half years. The length of their predecessors' tenures was just over eight years. As one business agent said speaking of the local leaders in this area, "I know of no official doing a reasonably good job who has been replaced. The ones who have been defeated were obviously derelict in their duties."

Eighteen out of the thirty people interviewed, or sixty percent, had fathers who were active unionists, carpenter, boilermaker, baker, printer, electrician, teamster, machinist, bricklayer, railroad worker to cite some of them. In two instances both mother and father were affiliated with unions. Only one business agent indicated that he came from a family where "both my father and grandfather we re strongly opposed to unions."

Three of the representative leaders I surveyed for this study are described in the following paragraphs:

F. D. is the business manager of one of the building trades locals. He is fifty years of age, a high school graduate, and a veteran of the C.Bs. He had worked at his trade for twenty-six years, twenty-one for one employer before quitting when asked to accept a position as assistant business agent in his local of which he had been recording secretary. He has now been elected to his second threeyear term as the administrative officer of his local. Mr. D. was proud of his role in the past in the construction of some of the city's largest and finest structures. He said he believed firmly in, "A day's work for a day's pay. A man who doesn't perform doesn't deserve a job. All the union does is refer him to the job. From there on he must produce." 
Mrs. E. H. is the secretary-treasurer of a union local which covers waitresses and hotel and restaurant employees. She is fortysix years of age, has had one year of college. E. H. has been a union member for twenty-seven years and was an assistant business agent of her local for three and one-half years before being elected to her present office. She had worked at her trade for twenty-two years and appeared quite willing to return to work if the membership was dissatisfied with her administration. She took pride in the skillful performance of the jobs in her local and stated that competent waitresses perform services difficult to automate.

R. H. is the business representative of a 1200 member local covering bakery and confectionary workers. He is fifty-nine years old, a high school graduate with two years attendance at a special trade school plus several night school classes. He has worked twenty-seven years at his trade, is a veteran of World War II. R. H. has been in office twelve years having been re-elected to six twoyear terms.

In interviewing these thirty local union leaders for this paper it was relatively easy to recognize and categorize them according to the divisions discussed in Chapter I. Three of the officers had obtained their jobs accidentally, two thrust into office through the sudden death of the incumbent, and one because no one else wanted the office and "It was my turn." Once in office at least one of these "accidental" leaders was clearly "ideological," stating that she "worked at this job, not from any need for income, but because of a very strong belief in Trade Unionism." Three of the officers interviewed were admittedly "ambitious" leaders. One forty-one-year-old newly elected business agent said that having worked as a salesman and under civil services for the federal government and obtaining very little personal satisfaction in either situation, he deliberately 
decided to join a craft union, advance through apprenticeship training and e ventually to administration within the union. (It took him seventeen years to attain his goal.) Another simply stated that personal initiative and ambition motivated him to run for office, while the third, a man under thirty, in office for five years, stated that he "wanted the personal satisfaction of bargaining and accomplishing something worthwhile for the local."

One "high-powered" leader was clearly evident in the business agent who spent much of his time on community affairs and was visibly indignant at the suggestion that these activities were not of too much practical benefit to his local. His specific comment was, "You're way off base." He may be right. His participation in community affairs on an equal basis with local professional and business men will do much to improve the image of labor leaders in the eyes of the public.

This leader, the business agent of a fourteen hundred member building trades' local, one of the oldest in the area (chartered December 1,1880 ) has been in office twenty-six years. He says that during this time organized labor, including his local, has done a great deal to correct the causes of industrial accidents in the state of Oregon and to compensate for the mishaps that seem unavoidable. During his first years in office, an industrial accident simply called for passing the hat. Meier and Frank could always be counted on to 
contribute along with some other large employers. He feels that this would still be the case if organized labor had not insisted on legislation to compensate injured workers.

Many of the business agents in this study indicated that this man was the "dean of local business agents." Only three local officers had been in office longer, two of whom were unpaid, and no one interviewed was as active in community affairs which includes being a director of the Oregon Museum of Science and Industry, first labor man on the Board of Directors of Blue Cross, and a member, just re-elected, of the Regional Planning and Development Commission.

A "managerial-officer" may be represented by the business agent interviewed who was actively interested in and discussed the salaries paid in industry for men willing to assume the kind of responsibility encountered in heading a large union local. Of course, if union office has been held for any appreciable length of time it might be difficult to return to the job site since much of the work of union members is too strenuous for an older person no longer accustomed to physical labor. Also, it is quite possible not to anticipate a return to the trade and still identify strongly with the working members of the local and to be effective in promoting the attainment of the local's goals.

The officer interviewed who best fits this description was the 
woman business agent, over sixty years of age, who had held her office for thirty-four years. Her chief concern was the improvernent of working conditions first, then higher wages in an industry whose wage earners were ninety-two percent women receiving an hourly wage of slightly over the federally established minumum.

A "managerial-officer" may not have an intense interest in job conditions because he is not going to personally experience them again. He has stepped out of the ranks of the blue collar worker and his first concern may be to see that he stays out. This might be accomplished by becoming a "social leader," well liked and trusted by a majority of the membership even though his demonstrated gains for the local are minimal. Or he might ingratiate himself with the business community that he encounters expecting some reciprocity should he be defeated for union office.

The business agent who was obviously proud of his skill as a workman and stated that "the experience gained as a business agent will help me as an iron worker," belongs to the "worker-officer" group, as does the business agent whose local by-laws allow an official to hold office for only one year. Every officer in this local must return to work for a year before running for office again. This arrangement is not as capricious as it seems at first glance for it insures a large group of workmen who have had experience in various union offices and provides the local with cfficers who have a very 
close working association with the membership. Another example of a "worker-officer" was the woman business agent who upon encountering a supposed lack of cooperation and support from the membership sincerely considered resigning her office and returning to work in the trade.

The "worker-officer" anticipating a return to the ranks may be more sensitive to the true needs and concerns of the workmen he represents. For instance, he does not view more pay as "the goal" for his local when actual experience has shown him that relief from an almost unbearable monotony is the one thing that could make the job more attractive; or, the change that would most benefit the workmen may be the elimination of hazardous working conditions. If the business agent expects to rejoin his fellow workmen, it is in his own best interest, as well as that of the local, to work hard to correct or improve any odious situation. To cite an example, if, for whatever reason, the union officer does not wish to work along side a member of a minority group and knows that a majority of the local members share his view, he will do little to integrate his local even though this is the publicly expressed position of the international office, as well as the law of the land.

Business agents recognized the fact that they were employees of rank and file (a term, incidentally, that was never used by the officers interviewed - membership seemed to be the favored desig- 
nation.) One business agent stated simply, "They feel that I am their employee." Another said, "I do whatever the membership requests," or, "I do everything in the local that no one else wants to do." Hoxie's description given in Chapter II is still a fairly good description of the duties of the business agent; but, the membership is no longer composed of the inarticulate workmen implied therein and a good part of the business agent's job is to keep the "membership happy." "

The business agents interviewed did seem to share certain personality characteristics. Using the Rutgers' Social Attribute Inventory (See Appendix B), wherein I rated the business agents on twenty-four traits, twenty-nine of the thirty were considered moderately or very good natured, all were intelligent, twenty-one of the thirty were relaxed, two were rated very tense but both were currently involved in unpleasant strike situations, one of which was nearly three months old and subject to a great deal of public criticism. All business agents were seen as strong, ambitious, mature, résponsible, self-reliant and sympathetic. As for physical characteristics, it is interesting to note that twenty-eight were tall and twentynine were rated relatively to very good looking, twenty-three were moderately thin, seven being slightly to moderately fat. All appeared to be conventional in appearance and attitude, the men were seen as moderately or very masculine and the three women as moderately or 
very feminine. Their jobs require them to be alert and adept at interpersonal relationships, apparently their personalities, as observed, would contribute to success on the job. (See Appendix B.) How well the business agents perform might also be indicated by the amount of time they spend on their various duties. As stated previously, only twenty-six of the thirty people interviewed were full-time paid administrators. Of the four who were not, three worked full-time at their trades and one was a retired unionist who thoroughly enjoyed being active in union affairs. Everyone of the remaining twenty-six spent at least forty hours a week on union business, sixty-eight percent of these spent over fifty hours each week at work. One business agent, who fortunately had no family, indicated that a one hundred hour or more work-week was routine for him. Another indicated that his normal work-week was seventyfive hours. The above figures are averages, when negotiations are in progress union activities could take up to 140 hours a week. One business agent recalled a recent experience wherein he attended a bargaining session with employers during the day, reporting to union members in the evening after a three hour drive, returning to another session with employers the next morning after the return three-hour trip only to repeat this performance twice again within the week before an agreement was reached. 
The non-union public, since it rarely personally encounters a business agent, must draw its view of union officials from local press media; and, the unusual activities of an agent, rather than his day=to-day work, are what make the headlines. As a result, many persons have an unfavorable concept of a business agent. According to Van Dusen Kennedy and Wilma Krauss the following four stereotypes represent some popular misconceptions of the business agent:

1. The labor racketeer. This stereotype includes the image of a big, brash, cigar-smoking agent who is seen as bullying the boss and union members to further his racketeering interests.

2. The radical agitator. This type is pictured as a young soapboxer who wants to take over management and to replace capitalism with socialism.

3. The management "stooge". This type has been pictured as a betrayer of labor who is in secret league with management.

4. The devoted idealist. This ste reotype pictures the agent as a martyr to the workers' cause who lives on a pittance and idealistically devotes all his time and energies to unionism. ${ }^{4}$

These four stereotypes are obvious exaggerations, at least none of the officers interviewed fits easily into any of the above categories. However, one such example of the views found currently in the nonunion public is in an interview with the president of the largest farmers' association in a three state area. ${ }^{5}$ Giving his personal

${ }^{4}$ Op. Cit., Kennedy, Van Dusen and Wilma Rule Krauss, pp.22-23

${ }^{5}$ Western Farmers' Association of Washington, Oregon, and Idaho. Personal interview, September, 1969. 
opinion, not the official position of his farm organization, this man stated that he saw a union business agent as:

.... a brusque, aggressive, domineering, unethical leader trained to manipulate the membership and make it antagonistic to management. The business agent's primary goal is the employment of every union member at higher wages for less work. He must develop a need for his services so that he can perpetuate his job. The business agent must be very forceful, organizing new members through intimidation.

No agent interviewed for this study fits the above description.

One assistant business agent did not $\epsilon$ ven want to be called a leader, stating, "I resent being referred to as a labor leader. I simply have a job to do and I do it to the best of my ability, but I'm no labor leader." Of course, as assistant, he is not technically the leader of his local, and in this instance the business agent did not share his re sentment.

In this survey it was not evident that one type of leader was superior to the other -- some "ambitious" or "managerial-officers" working most aggressively to promote the goals of their locals and through success here achieve personal satisfaction; while some "ideological" or "worker-officers" seemed to work just as hard to achieve what their memberships wanted. The latter type however seemed to exhibit more pride in the craft or industry with which he was connected and was more comfortable in discussing all aspects of his local and his role in its administration. 
The business agent represents the workers of his local on all questions which arise concerning the job and the union contract: questions over pay, working conditions, vacations, overtime, holidays, work rules, safety, promotions, lay-offs. One of his most important duties is to represent the union members in new contract negotiations - a function that $80 \%$ of the officials in this sample considered their most important responsibility. However, the modern business agent's duties go beyond the bread and butter issues. He is consulted on family problems, legal and social problems. Wives phone him to verify employment locations. One local has attorneys on retainer to whom the union member can turn for free advice. One business agent stated, "I feel like a Catholic priest, I've heard so many confessions." Today's business agent seems to view himself more as a fellow unionist and personal friend, than as a labor leader. How business agents perceive the goals of their locals and work to implement them can have a widespread effect on the community's economy. More than one business agent stated that his local believed in, "A good day's pay for a good day's work." None of those interviewed suggested the concept of more pay for less work, and more than one business agent volunteered the thought that the employer must make a profit to stay in business and provide the jobs that his local is filling.

In this survey, the business agents had two recurring goals, 
improvement of living standards through better wages and fringe benefits, and improvement of working conditions. After wages and working conditions the next most frequently mentioned target was an increase in union membership either through an expansion of jurisdiction or through the unionizing of hold-out units. One officer stated frankly that the goal of his local was full employment for a minimum number of workers, asking, "Isn't that what every union local wants?" If it is no other business agent mentioned it, and this goal is inconsistent with that previously mentioned of enlarging membership. Of course, increasing membership by admitting workers who already have jobs is a different situation from opening up admissions to an apprenticeship program in a craft union and training a number of young workers who will then compete with older ones for the available jobs. One business agent stated his primary goal as that of establishing a seniority system in his local, because, especially in places requiring physical labor, employers have a preference for younger workers. Another explicitly stated goal was the maintenance of the high (one could read this rigid) standards prevailing in his trade. This appeared as an unwillingness to accept the use of new materials requiring less labor.

Only some of the business agents interviewed indicated no color preference in their membership. In fact it seems that one way to maintain work standards is to screen applicants for union member- 
ship very carefully, eliminating any who have police records, and one business agent stated that those with records "as a rule are Negroes." Another volunteered the comment, "If anything ruins the unions, the Negroes' insistence on membership will. The whole system will collapse - we'll be a coffee-colored race." The business agent of one local with a number of Negro workers stated that the Negroes were always assigned to a particularly unpleasant procedure because the white workers refused the assignment as being too hard. But when the union negotiated premium pay for this task, the white workers suddenly found it easier and insisted on sharing this work.

Business agents see apathy of the membership as one of the major obstacles to achieving their goals. Examples of some of their statements are: "Members take everything for granted, they won't attend union meetings unless it's contract time, then you get a $90 \%$ turnout." "They want all the benefits but none of the responsibilities connected with union membership." Some of the officers think this situation might be resolved through compulsory attendance. One local that has a modest fine for non-attendance did not solve its problems. The members simply looked upon the fine as another assessment and stayed away. The only officer satisfied with membership participation is the one from the local in which all officers are replaced every year. Working conditions in this local also happen to present ample opportunities for the men to work in groups that change 
constantly so that there is a great deal of personal contact between all the members. Authors, such as Arnold S. Tannenbaum and Robert L. Kahn discussed this problem of participation. ${ }^{6}$ The problem has not yet been solved. If anything, union members have become more apathetic, and, the business agent, who can ove rcome this situation, will have done his local, his union, and the labor movement in general a real service.

Many of these local officers felt that their jobs could be made easier by repeal of restrictive legislation, particularly Section $14 \mathrm{~b}$ of the Taft-Hartley Act. Some of the locals connected with the building trades wanted legislation to allow situs picketing, others wanted inspection codes relaxed and restrictive state laws repealed. However, they generally agreed that labor legislation was cyclical, favorable laws being followed by restrictive ones, which would eventually be modified by more favorable laws. Many thought that public opinion influenced the way workers viewed their union and thus affected their degree of participation. One business agent, whose trade is rated the second most hazardous, said that if the public just understood what the se workmen do, they would insist on more favorable labor legislation.

${ }^{6}$ Tannenbaum, Arnold S. and Robert L. Kahn. Participation in Union Locals, Evanston, Ill. , Row, Peterson \& Co., 1958, pp. $111-152$. 


\section{CHAPTER IV}

\section{MONETARY AND NON-MONETARY RETURNS TO PORTLAND BUSINESS AGENTS}

As with any organization, local labor unions also have had to deal with the philosophy and means to compensate their officers for leadership services. In this chapter, detailed data on salaries of agents are first presented followed by several categories of nonmonetary remuneration. Until 1959 little data were available on salaries of business agents. In 1949, Eli Ginzberg stated:

Several unions, among them the Ladies' Garment Workers, have recently reversed the long-established policy of financial secrecy and have begun to publish detailed reports. But this is recent and still exceptional. Despite the paucity of available data, an effort can be made to piece together the financial history of these unions. A reasonable approximation can be made of their income and their expenditure accounts can be partially unraveled. 1

Passage of the Landrum-Griffin Bill in 1959 made possible for the first time, an approximation of the expenditures of a local union by the public.

Every labor organization shall file annually with the Secretary (Secretary of Labor) a financial report signed by its president and treasurer or corresponding principal officers containing the following information in such detail as may be necessary accurately to

1

Ginzberg, Eli. The Labor Leader: An Exploratory Study, New York: The MacMillan Co., 1948, p. 71. 
disclose its financial condition and operations for its preceding fiscal year...

- . salary, allowance, and other direct or indirect disbursements (including, reimbursed expenses) to each officer... 2

And according to Section 205 (b) of the same bill:

The Secretary shall by regulation make reasonable provision for the inspection and examination, on the request of any person, of the information and data contained in any report or other document filed with him pursuant to Section 201,202 , or $203 .^{3}$

Although this law had already been in effect ten years when this survey was made, one business agent interviewed stated, "My salary is none of your business," and was startled to find that his salary was a matter of public record.

Table IV, on the following page, lists the salaries received by thirty business agents interviewed in this study. Also given is the total membership of each local, the membership rank of each local, and the per capita amount paid by each union member to support his business agent.

Annual salaries for business agents ranged from $\$ 8,234$ to $\$ 23,513$, with a median of $\$ 12,906$. The lowest salary for a business agent was almost double the salary of the average worker in that local, and the highest was certainly more than double the average for workers in that business agent's local. There were several more instances where business agents received about twice the pay of the union workmen.

2 Complete copy of Public Law 86-257, commonly known as Landrum-Griffin Bill. Portland, Oregon: Beaver Press 1959, pp. 14-15. 3 Ibid. , p. 24. 
TABLE IV

BUSINESS AGENTS' SALARIES, MEMBERSHIP, PER CAPITA COSTS, 1969

\begin{tabular}{|c|c|c|c|c|}
\hline Name of Locals & $\begin{array}{l}\text { Business } \\
\text { Agents' } \\
\text { Salaries } \\
(1967)^{1}\end{array}$ & $\begin{array}{c}\text { Local Union } \\
\text { Membęr - } \\
\text { ship }\end{array}$ & $\begin{array}{l}\text { Per Capita } \\
\text { Cost of } \\
\text { Agents' } \\
\text { Salaries } 3 \\
\end{array}$ & $\begin{array}{l}\text { Member- } \\
\text { ship } \\
\text { Rank }\end{array}$ \\
\hline $\begin{array}{l}\text { L. U. } 701 \text { - Hoisting \& } \\
\text { Portable Engineers. }\end{array}$ & $\$ 23,513.32$ & 5,800 & $\$ 4$. & 1 \\
\hline 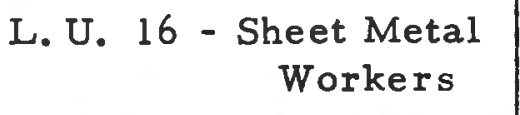 & $17,004.00$ & 1,400 & 12. & 11 \\
\hline $\begin{aligned} \text { L. U. } 29- & \text { Iron } \\
& \text { Workers }\end{aligned}$ & $16,415.00$ & 900 & 18. & 17 \\
\hline $\begin{array}{l}\text { L. U. } 48 \text { - Electrical } \\
\text { Workers (I. B.E. W.) }\end{array}$ & $16,213.47$ & 1,700 & 10 & 8 \\
\hline $\begin{aligned} & \text { L. U. } 162 \text { - General } \\
& \text { Teamsters - } \\
& \text { President - } \\
& \text { B.A.'s Sal. - }\end{aligned}$ & $\begin{array}{l}16,009.00 \\
22,127.00\end{array}$ & 4,400 & 4. & 2 \\
\hline $\begin{array}{l}\text { L. U. } 11 \text { - Office Em- } \\
\text { ployees, Professional } \\
\text { \& Technical }\end{array}$ & $14,358.00$ & 2,000 & 7. & 5 \\
\hline L. U. $1257-\begin{array}{l}\text { Retail } \\
\text { Clerks }\end{array}$ & $14,236.27$ & 1,700 & 8. & 8 \\
\hline L.U. 51 - Plumbers & $14,021.00$ & 700 & 20. & 19 \\
\hline L. U. 656 - Butchers & $13,619.00$ & 836 & 16. & 18 \\
\hline $\begin{array}{l}\text { L. U. } 544 \text { - Sheet } \\
\text { Metal Workers }\end{array}$ & $13,494.82$ & 1,200 & 11 & 13 \\
\hline Lodge \#63-Machinists & $13,331.00$ & 3,400 & 4. & 3 \\
\hline L.U. 143 - Meat Cutters & $13,130.00$ & 1,700 & 8. & 8 \\
\hline
\end{tabular}




\begin{tabular}{|c|c|c|c|c|}
\hline Name of Locals & $\begin{array}{l}\text { Business } \\
\text { Agents } \\
\text { Salaries } \\
(1967)^{1}\end{array}$ & $\begin{array}{l}\text { Local Union } \\
\text { Member- } \\
\text { ship }\end{array}$ & $\begin{array}{l}\text { Per Capita } \\
\text { Cost of } \\
\text { Agents' } \\
\text { Salaries }\end{array}$ & $\begin{array}{l}\text { Member- } \\
\text { ship } \\
\text { Rank }\end{array}$ \\
\hline L.U. 1 - $\begin{array}{c}\text { Bricklayers \& } \\
\text { Masons }\end{array}$ & $\$ 12,681.75$ & 530 & $\$ 24$ & 21 \\
\hline $\begin{array}{l}\text { L. U. } 114 \text { - Bakers \& } \\
\text { Confectionary Worker }\end{array}$ & $12,418.76$ & 1,170 & 11. & 15 \\
\hline L. U. 82 - Plasterers & $12,246.00$ & 140 & 87. & 27 \\
\hline $\begin{array}{l}\text { L. U. } 8 \text { - Longshoremen } \\
\text { \& Warehousemen }\end{array}$ & $12,000.00$ & 1,000 & 12. & 16 \\
\hline $\begin{array}{l}\text { L. U. } 296 \text { - Laborers \& } \\
\text { Hod Carriers }\end{array}$ & $11,963.36$ & 2,000 & 6. & 5 \\
\hline $\begin{array}{r}\text { L. U. } 36 \text { - Asbestos } \\
\text { Workers }\end{array}$ & $11,398.26$ & 141 & 81 . & 28 \\
\hline L. U. 496 - Bartenders & $11,200.00$ & 1,200 & 9. & 13 \\
\hline $\begin{array}{l}\text { L. U. } 107 \text { - Laundry \& } \\
\text { Dry Cleaning } \\
\text { Workers }\end{array}$ & $10,400.00$ & 1,800 & 6. & 7 \\
\hline $\begin{array}{l}\text { Sailors Union of } \\
\text { Pacific } \quad \text { (Inland } \\
\text { Boatmen) }\end{array}$ & $9,706.00$ & 400 & 24 & 23 \\
\hline $\begin{array}{l}\text { L. U. } 231 \text { - Egg \& } \\
\text { Poultry Workers }\end{array}$ & $9,254.00$ & 500 & 19. & 22 \\
\hline $\begin{array}{l}\text { L. U. } 58 \text { - Typograph- } \\
\text { ical Union }\end{array}$ & $9,203.55$ & 350 & 26. & 24 \\
\hline $\begin{array}{r}\text { L. U. } 3182-\text { Furniture } \\
\text { Workers }\end{array}$ & $8,758.47$ & 700 & 13. & 19 \\
\hline $\begin{array}{l}\text { L.U. } 17 \text { - Masters, } \\
\text { Mates \& Pilots }\end{array}$ & $8,586.92$ & 230 & 37. & 25 \\
\hline
\end{tabular}




\begin{tabular}{l|c|c|c|c} 
Name of Locals & $\begin{array}{l}\text { Business } \\
\text { Agents' } \\
\text { Salaries } \\
(1967)^{1}\end{array}$ & $\begin{array}{c}\text { Local Union } \\
\text { Member- } \\
\text { ship }\end{array}$ & $\begin{array}{c}\text { Per Capita } \\
\text { Cost of } \\
\text { Agents } \\
\text { Salaries }\end{array}$ & $\begin{array}{c}\text { Member- } \\
\text { ship } \\
\text { Rank }\end{array}$ \\
\hline \begin{tabular}{l} 
L.U. 305 - Waitresses \\
\hline $\begin{array}{l}\text { L. U. } 9201 \text { - Com- } \\
\text { munications } \\
\text { Workers* }\end{array}$
\end{tabular} & $8,234.00$ & 2,137 & $\$ 4$. & 4 \\
\hline $\begin{array}{l}\text { L. U. B-20 - Theatrical } \\
\text { \& Stage Employees* }\end{array}$ & 0 & 1,400 & 0 & 11 \\
\hline $\begin{array}{c}\text { L. U. } 41 \text { - Jewelry } \\
\text { Workers* }\end{array}$ & 0 & 200 & 0 & 26 \\
\hline $\begin{array}{c}\text { L. U. } 70 \text { - Garment } \\
\text { Workers* }\end{array}$ & 0 & 82 & 0 & 29 \\
\hline \hline
\end{tabular}

*Business agents work full-time at trade and are not paid a salary by their locals; L. U. 9201 and L. U. B-20 reimburse agents for expenses.

${ }^{1}$ Data from form LM-3 for 1967, latest figures available at time of study.

2 Estimated from total dues paid as listed on form LM-3 and verified with the various business agents. Local union membership figures are subject to fluctuation in the course of a year, and while some of the figures given are the exact membership at the time of the interview, others are an average for the year 1967, the latest figures available at the time of the study.

${ }^{3}$ The amount each member contributes annually to the business agent's salary; computed by dividing 'Business Agents salaries' of column 1 by 'Local Union Membership' of column 2.

Source: Form LM-3 required by Section 201 (b) of the Landrum-Griffin Bill. Forms are on file in Office of LaborManagement and Welfare-Pension Reports in Portland, Oregon. 
The third column of Table IV indicates per capita cost of agents' salaries varied widely in the sampled local unions. The range was from $\$ 4.00$ annually in several locals to a high of $\$ 87.00$. This variance likely did not represent the actual differences in services provided by individual business agents.

As noted in Table IV, only twenty-six of the business agents in this survey were full-time paid union officials, the remaining four worked full-time at their trades; and, while two of them were reimbursed for expenses incurred in conducting union business, two received no compensation at all for this extra activity.

As indicated above, the median income of the twenty-six, fulltime business agents was $\$ 12,906.00$. According to the 1970 census, a median salary of $\$ 9,822.00$ was received by Specified Managers and Administrators, a roughly comparable occupational category. 4 Thus, business agents in this survey were receiving about onefourth more than they could expect to earn from similar work in industry.

In almost every case studied, business agents' salaries must be approved by vote of the membership. The method most used in determining the business agent's salary was setting the agent's salary equal to the "highest foremen's wages" paid in the trade. In

${ }^{4}$ U. S. Bureau of Census, 1970, Characteristics of the Population for Oregon. Table 175, Part 3, p. 450 
some cases either a specified, or unspecified, amount of overtime pay was added to this base. For example, one business agent received \$17,004 annually, which was set by the membership "based on the negotiated rate in the industry plus a certain amount of overtime." Since the negotiated rate for a journeyman in this industry was $\$ 5.05$ per hour at the time, the agent's $\$ 17,004$ salary contained approximately $\$ 7,000$ in overtime.

Only one local surveyed based its business agent's salary on the regular hourly journeyman's rate, which resulted in this business agent receiving a lower salary than all the foremen in that local. However, this may have occurred because in this particular trade the members could not always count on working forty hours a week on a year-round basis, making their business agent's wage rate more attractive than it appeared. In all the other cases, the local union official's salary compared favorably to that of his fellow unionists.

There are a number of factors which affect the business agent's salary. One which seems significant is the size of union membership; the larger the membership, the larger the salary paid. One local in fact computes its business agent's salary on membership. If one of the goals of this local is to increase membership, then the business agent's salary may be a measure of how successful he has been in achieving this goal.

Testing the significance of membership, a linear correlation 
was calculated relating membership to business agent's salary. Using the figures in Table IV (pages $41-43$ ), the equation was: $s=10.03+.21 \mathrm{~m}$, where $s$ is salary and $\mathrm{m}$ is membership. The coefficient of correlation between salary and size of membership is $\mathbf{r}=0.732$. At a ninety-five percent confidence level, this is statistically significant. 5 If one looks only at the eight locals in Table IV whose workers might be considered unskilled, the coefficient of correlation between size of membership and the business agent's salary is $r=0.788 .^{6}$ At a ninety-five percent confidence level, this too is statistically significant.

Another factor seeming to influence the salary level is the level of skill of the trade that the local represents. If it is composed of highly skilled workers, not easily replaced by untrained recruits, the pay scale tends to be higher, and the business agent usually receives the highest scale in the industry plus some overtime. Alternatively, if the wage scale is rather close to the federal minimum, which appears to be more likely in the unlicensed trades, or in those requiring less skill and little training, then the business agent tends to receive a lower salary, but one which is still about twice that of the working members of the local. According to several business agents,

$$
\begin{aligned}
& 5 t=5.27 \text {, at } .95 \text { confidence level } \\
& 6_{t}=3.20 \text {, at } .95 \text { confidence level }
\end{aligned}
$$


this is done in order to put him on a more equal footing with the employers with whom he must negotiate.

In addition to the monetary remunerations there are nonmonetary rewards in holding a paid union office that may make the job attractive. Some business agents control large sums of money. For example, one 1,700 member local has dues of $\$ 240.00$ per year. Thus, its business agent controls a minimum of $\$ 408,000$. Actually he handles a much larger sum for contributions to the pension plan and the health and welfare plan come into his office directly from the employers.

The above figure is not unusual. One local in this survey reported an income from dues and fees of $\$ 767,763.00$ for the year 1967. Control of such funds can make the business agent powerful indeed and responsibility for this kind of income will require precise accounting procedures and personal integrity on the part of union officers. One business agent, who had been in office for twenty-six years, was emphatic about the honesty of local union officials, stating, "There is just no place in the local labor movement for dishonesty." However, two of the officers interviewed admitted quite readily that they were in office because their predecessors had "his hand in the till," or "got the union funds mixed up with his own." One business agent still recalls that when he was first elected to office seventeen years ago his neighbor remarked, "Well, you've 
got it made now, you've got control of a union local."

Business agents also have a certain amount of power and prestige. They have been set apart, some might say set above, their friends and erstwhile fellow workmen. In many instances they have power to allocate jobs, their special friends and supporters getting the more desirable referrals. In at least one instance a business agent was able to force a fellow union member into another line of work by simply refusing him a job assignment on some pretext. Business agents occasionally exercise a certain amount of power over employers, sending a favored one top-notch workers and a less favored one workers who turn out to be marginal at best. Such a situation can be quite satisfying, especially if the business agent has a score to settle with a particular employer. It is only fair to indicate that this attitude was rare, a more common attitude was one of cooperation and mutual assistance.

Local business agents have many opportunities to travel at union expense and there is also the possibility of becoming a publicly recognized figure, which is appealing to some. Five of the business agents in this survey have been interviewed on local television news programs in the past year and many of them are frequently referred to and quoted in the local press.

In addition to the rewards mentioned above, business agents have an opportunity to work in clean, pleasant surroundings. Con- 
trary to the study of business agents in the San Francisco Bay area, previously mentioned, which noted that:

Business agents usually do not have fancy places to work in. Most union offices are simply furnished. Often they are barren with little more than a certificate of union affiliation or some times a few union posters or photographs of union officials to decorate the walls. The office is usually in a moderate rental building, rarely in a high-priced or new structure. ${ }^{7}$

Portland, Oregon area business agents work in high-priced, very comfortable, even plush surroundings. One-third of those interviewed had offices in a new Labor Center, an attractive building with landscaped grounds and ample parking facilities on the site. Almost a third of the remainder maintained offices in buildings belonging to their respective locals. The se buildings were at the most ten years old, and in one instance the building covered an entire city block. The remaining third rented space in either new buildings out of the downtown area or in tastefully remodelled older buildings in the city center. As one business agent stated, "You'd be a fool not to prefer an office, a suit, and clean hands, to the grime of the factory or construction site."

${ }^{7}$ Kennedy. op. cit., p. 33. 


\section{CHAPTER V}

\section{SUMMARY AND CONCLUSIONS}

This study found that business agents, who represent local union workers, in the Portland, Oregon area, and are responsible for the attainment of union goals, a re mature, responsible, optimistic, and willing to work long hours to fulfill their job duties. The agents' rewards, both monetary and non-monetary, seem adequate in relation to their responsibilities according to both the size of the local membership and the amount of union money they control.

Leonard R. Sayles, writing in 1953 and restating his observations in 1967 , said:

- . In any case, the pay of the average organizer or business agent is so little higher than the usual salary that is paid to the skilled worker, that the financial attractions of the job are rather slight. 1

In 1955, restated in 1964, Van Dusen Kennedy commented:

- . Since the income of a business agent is usually somewhat higher than that of the average member of his union, it is not unfair to assume that this is one factor which helps to make the job attractive. 2

1

Sayles. op. cit., p. 67.

${ }^{2}$ Kennedy. op. cit., p. 30. 
Observations from this study seem to substantiate the divergent findings on salaries of these previous studies of local business agents. In the skilled trades business agents do receive a salary comparable to the regularly employed union worker. On the other hand, in the unskilled groups business agents' salaries are much higher than could be earned from working full-time at the trade.

Ninety percent of the business agents in this survey were men usually representing locals with one hundred percent male membership. Two exceptions were Local No. 11, Office Employees, Professional and Technical; and Local No. 1257, Retail Clerks; both of which have memberships of at least seventy percent women. The remaining three business agents were women who represented locals composed primarily, but not exclusively, of women workers.

Ninety percent of the business agents were over forty years old and had been union members for at least fifteen years. With one exception all came from families with union backgrounds and worked their way through the ranks. Two business agents admitted to having plans to attain the position even before they were admitted to union membership. One agent said that he advised a man with a college degree who wanted to work in local union management, to apply for membership in the local of his choice and $r$ un for whatever office was open, this being his only way into union management.

Only ten percent of the agents interviewed had college degrees 
although seven (23\%) had some college work. Fifty-three percent ended their formal education with high school, while the remaining four (13\%) ended formal education with less than high school. Thus, as a group, business agents were older, had less education, and earned more than men holding comparable positions in industry. Along with pursuing the locals' "bread and butter" goals of better wages and working conditions, these business agents were actively promoting pride in and satisfaction with the unions' contributions to the economy of the Portland area.

Leadership is more than competence and efficiency in negotiating and administering a contract, more than "servicing" the membership; it is also inspiring union members to a pride in and a satisfaction with a job well done; it is providing a framework wherein social recognition and fulfillment can be attained. 


\section{- APPENDIX A}

LOCAL UNIONS STUDIED, PORTLAND, OREGON

Asbestos Workers, Local 36

Fakers \& Confectionery Workers, Local 114

Bartenders, Local 496

Bricklayers \& Masons, Local 1

Butchers, Local 656

Communication Workers, Local 9201

Egg \& Poultry Workers, Local 231

Electrical Workers, Local 48

Engineers, Local 801 -- Hoisting \& Portable

Furniture Workers, Local 1090

Garment Workers, Local 70

Iron Workers, Local 29

Jewelry Workers, Local 41

Laborers, Local 296

Laundry \& Dry Cleaning Workers, Local 107

Longshoremen's \& Warehousemen's Local 8

Machinists, Local 63

Masters, Mates \& Pilots, Local 17

Meat Cutters, Local 143

Office Employees, Professional \& Technical, Local 11 
Plasterers, Local 82

Plumbers, Local 51

Retail Clerks, Local 1257

Sailors Union of the Pacific

Sheet Metal Workers, Local 544

Sheet Metal Workers, Local 16

Teamsters, Local 162

Theatrical Employees, Local B-20

Typographical Union, Local 58

Waitresses Union, Local 305 
APPENDIX B

RUTGERS' SOCIAL ATTRIBUTE INVENTORY

Number of Business Agents in Each Rank

\begin{tabular}{l|r|r|r|l|l|l|l}
\hline \hline 1. good-natured & 19 & 8 & 2 & stubborn & & & 1 \\
\hline 2. intelligent & 9 & 19 & 2 & unintelligent & & & \\
\hline 3. tense & 1 & 1 & 7 & relaxed & 6 & 14 & 1 \\
\hline 4. strong & 11 & 15 & 3 & weak & & & 1 \\
\hline 5. childish & & & & mature & 9 & 17 & 4 \\
\hline 6. old-fashioned & & 6 & 13 & modern & 1 & 8 & 2 \\
\hline 7. dominating & 3 & 9 & 13 & submissive & & 1 & 4 \\
\hline 8. thin & & 22 & & fat & & 3 & 5 \\
\hline 9. adventurous & 1 & 11 & 7 & cautious & 2 & 7 & 2 \\
\hline 10. lazy & & & & ambitious & 6 & 21 & 3 \\
\hline 11. optimistic & 7 & 14 & 4 & pessimistic & & 1 & 3 \\
\hline 12. masculine & 6 & 20 & 1 & feminine & 2 & 1 & \\
\hline 13. young & 1 & 15 & 6 & old & & 5 & 3 \\
\hline 14. responsible & 15 & 15 & & irresponsible & & & \\
\hline 15. crude & & & 1 & refined & 2 & 24 & 3 \\
\hline 16. tall & & 27 & & short & 1 & 2 & \\
\hline 17. suspicious & 1 & 4 & 1 & trusting & 6 & 18 & \\
\hline 18. talkative & 3 & 15 & 9 & quiet & & 3 & \\
\hline 19. thrifty & NA & NA & NA & wasteful & NA & NA & NA \\
\hline 20. dependent & & & & self-reliant & 10 & 20 & \\
\hline 22. good-looking & 2 & 17 & 9 & plain & & 2 & \\
\hline
\end{tabular}




\begin{tabular}{l|c|c|c|c|c|c|c}
\hline & Very & Mod & Slight & & Very & Mod. & Slight \\
\hline 23. conventional & & 20 & 10 & unconventional & & & \\
\hline 24. rich & NA & NA & NA & poor & NA & NA & NA \\
\hline
\end{tabular}

1959 Adult Ratings of others on 24 traits, William D. Wells, Psychometric Affiliates

NA: Not applicable for this study.

Obtained from Psychology Dept. Portland State University. (William D. Wells Psychometric Affiliates.) 


\section{APPENDIX C}

\section{INTERVIEW QUESTIONNAIRE}

1. Sex Male Female

2. Age $20-2930-39$ 40-49 50-59 over 60

3. Marital status $\overline{\text { Sing. }} \overline{\text { Mar. }} \overline{\text { Div., Widowed, Sep. }}$

4. Dependents other than subject $\overline{2 \text { or less }} \overline{3-5} \overline{6 \text { or more }}$

5. Title of union office held

6. How many years in this office

7. Years predecessor held office

8. Total number of years as union member

9. What other union office held $\overline{\text { Pres. }} \overline{\text { V.P. }} \overline{\text { Rec.Sec. Other }}$

10. On average, how many hours per week spent on all union duties combined

$$
\overline{0-9} \overline{10-19} \overline{20-29} \overline{30-39} \overline{40-49} \overline{50 \text { or more }}
$$

11. In past 3 months, what has been the largest number of hours spent in union business in any one week smalle st no.

12. If you could change one condition which exists within the local, which condition would you change if you wanted to benefit the local most?

13. Which one of the following outside conditions would you change if you wanted to benefit the local the most? public opinion management practices other ec onomic conditions 
14. How much do you think the membership has to say about how thing s are decided in local?

Members

Executive board

Bargaining Committee

a great deal

a fair amount

some

very little

no say at all

15. Have you ever been in other occupations?

$\overline{\text { Yes }} \overline{\text { No }} \overline{\text { Chiefly what? }}$

16. Is your wife (husband) a union member?

$$
\overline{\text { Yes }} \overline{\text { No }} \text {. }
$$

17. Does your wife (husband) approve of your union activity?

Yes No

18. Was your father a union member?

$$
\overline{\text { Yes }} \overline{\text { No Occupation }}
$$

19. Have you ever been unemployed?

Less than 30 days $\overline{\text { about } 30 \text { days }}$

$$
\text { more than } 30 \text { days }
$$

20. School background

$$
\text { Grade High College }
$$

21. What would you say is your chief source of news about union affairs?

22. Chief source of news about current events. (Check one)

$\overline{\text { radio }} \overline{\text { local paper }} \overline{\text { unionpaper }} \overline{\text { magazines }} \overline{\text { other }}$

23. Do you read the union paper regularly?

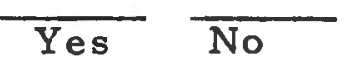

24. What magazines do you read regularly? None, Reader's Di., Newsweek, Time, US News - , Coronet, Life, Look, Union Mag. ,. Other. 
25. Have you read any books within the past six months? Yes No How many What

26. Do you belong to other organizations besides your union? Yes No Name

27. How well off financially do you think (union) working people in the U.S. are at present time? Very well off Medium well off Poorly off Well off Very poorly off Non-union?

28. How well off will they be next year?

$$
\text { Union Non-union }
$$

29. Can the government do anything to prevent unemployment resulting from slack business conditions? Yes No

30. Can union members do anything to prevent unemployment resulting from slack business conditions? Yes No

31. What can unions do to prevent unemployment resulting from automation?

32. What are the most important responsibilities of your office? What are you most concerned about?

What kinds of specific things do you do to try to carry out your responsibilities?

Of the things you do, which one thing is the most important? Why?

33. Of all the things you do as a union officer, which things take the most of your time?

34. What are the goals, or aims, of your local? What is your local after? What is it trying to do? 
35. How do you view the future of your local? Of the labor movement in general?

36. Is your local making progress compared to others? Improving its position?

37. Accessibility - - Relationship with membership.

38. Constraint or direction from International?

39. Training program for newly elected local union officers?

40. Any specific deciding factor in your decision to $r$ un for office of B.A.?

41. Any particular surprises on the job?

Source: Adapted from Miller, Robert W., Frederick A. Zeller, Glenn W. Miller. The Practice of Local Union Leadership, Columbus: Ohio State University Press, 1965. 


\section{BIBLIOGRA PHY}

Adamic, Louis, Dynamite: The Story of Class Violence in America, Revised Edition, Gloucester, Mass., Peter Smith, 1963.

Barbash, Jack. Labor's Grass Roots, New York, Harper \& Brothers, 1961.

Barbash, Jack. Labor Unions in Action, New York: Harper \& Brothers, 1948.

Barbash; Jack. Unions and Union Leadership, New York: Harper \& Brothers, 1959.

Beirne, Joseph A. New Horizons for American Labor, Washington, D. C. Public Affairs Press, 1962.

Bogardus, Emory S. Leaders and Leadership, New York:

D. Appleton-Century, Inc., 1934.

Gouldner, Alvin W. "Attitudes of 'Progressive' Trade Union

Leaders," American Journal of Sociology, LII (1947).

Hardman, J.B.S. and Maurice F. Neufeld. The House of Labor, New York: Prentice-Hall, Inc., 1951.

Hoxie, Robert Franklin. Trade Unionism in the United States, New York, D. Appleton and Company, 1917.

International Brotherhood of Electrical Workers. Historyand Structure of the IBEW, Washington, D.C., 1967.

Kennedy, Van Dusen and Wilma Rule Krauss. The Business Agent and His Union, Berkeley, Institute of Industrial Relations, University of California, 1964.

Levine, Solomon B. and Bernard Karsh. "Industrial Relations for the Next Generation, "Quarterly Review of Economics and Business, (Feb. 1961).

Miernyk, William $H$. Trade Unions in the Age of Affluence, New York: Random House, 1962. 
Miller, Robert W., Frederick A. Zeller, Glenn W. Miller. The Practice of Local Union Leadership, Columbus: Ohio State University Press, 1965.

Neufeld, Maurice. Day In and Out with Local 3, IBEW, Ithaca: Cornell University Press, 1951.

Public Law 86-259, commonly known as Landrum-Griffin Bill. Portland, Oregon: Beaver Press, 1959.

Sayles, Leonard R, and George Strauss, The Local Union: Its Place in the Industrial Plant, New York, Harper \& Brothers, 1953.

Seidman, Harold. Labor Czars, New York: Liveright Publishing Corporation, 1938.

Stone, Irving. "Calvin Coolidge: A Study in Inertia," The Aspirin Age, Ed., Isabel Leighton, New York: Simon \& Schuster Inc., 1949.

"The Royal Families," Fortune, December, 1968.

U.S. Census Data, 1970.

Weiss, Leonard W. Economics and Society, New York: John Wiley \& Sons, 1975. 